\title{
Pengaruh Bimbingan Belajar Terhadap Prestasi Belajar Siswa
}

(Studi Kasus SMA Mulia Buana Parung Panjang)

\author{
Denny Erica $^{(1)}$, Ibnu Dwi Lesmono ${ }^{(2)}$ \\ denny.dea@bsi.ac.id \\ ${ }^{(1,2)}$ Dosen Fakultas Teknologi Informasi Universitas Bina Sarana Informatika
}

\begin{abstract}
Abstrak
Penelitian ini bertujuan untuk menemukan jawaban dan menjelaskan pengaruh pembelajaran pada siswa, hubungan antara dimensi variabel pembelajaran dan variabel prestasi belajar siswa pada siswa. SMA Mulia Buana Parung Panjang. Metode penelitian ini adalah metode pendekatan kuantitatif yang menguji data untuk menguji atau menguji koefisien korelasi $r$. Hasil yang diperoleh $r$ hitung sebesar 0,412, sedangkan $r$ tabel pada taraf signifikansi 5\% adalah 0,361 sehingga $r$ hitung $>r$ tabel. Dari perhitungan, t hitung sama dengan 2.393 lebih jauh dari t tabel harga pada tingkat signifikansi $5 \%$ dan $\mathrm{db}=\mathrm{n}-2$. Jadi db adalah 30-2 $=28$. Kemudian t tabel diperoleh pada level signifikan $5 \%=1.701$. Ternyata $\mathrm{t}>\mathrm{t}$ tabel. Berdasarkan pengolahan data di atas $\mathrm{r}$ hitung 0,412>0,361 tabel $\mathrm{r}$ sehingga Ha diterima. Ini berarti ada hubungan yang signifikan antara bimbingan belajar dan prestasi akademik di SMA Mulia Buana Parung Panjang, karena pada kisaran antara 0,400 hingga 0,599 adalah 0,412. Pentingnya pembelajaran dalam kategori sedang yang perlu ditingkatkan dalam kategori bimbingan belajar adalah untuk menjaga kelangsungan prestasi belajar siswa di SMA Mulia Buana Parung Panjang.
\end{abstract}

Kata kunci: bimbingan belajar, prestasi belajar. 


\section{PENDAHULUAN}

Pendidikan pada hakekatnya adalah usaha membudayakan manusia atau memanusiakan manusia. pendidikan amat strategis untuk mencerdaskan kehidupan bangsa dan diperlukan guna meningkatkan mutu bangsa secara menyeluruh. Pendidikan adalah usaha sadar dan terencana untuk mewujudkan suasana belajar dan proses pembelajaran agar peserta didik secara aktif mengembangkan potensi dirinya untuk memiliki kekuatan spiritual keagamaan, pengendalian diri, kepribadian, kecerdasan, akhlak mulia. serta ketrampilan yang diperlukan dirinya, masyarakat, bangsa dan negara.

Penyelenggaraan pendidikan di Indonesia merupakan suatu sistem pendidikan nasional yang diatur secara sistematis. Pendidikan nasional berfungsi mengembangkan kemampuan dan membentuk watak serta peradaban bangsa yang bermartabat dalam rangka mencerdaskan kehidupan bangsa, bertujuan untuk berkembangnya potensi peserta didik agar menjadi manusia yang beriman dan bertakwa kepada Tuhan Yang Maha Esa, berakhlak mulia, sehat, berilmu, cakap, kreatif, mandiri, dan menjadi warga negara yang demokratis serta bertanggung jawab (UU No. 20 Tahun 2003).

Pada SMA MULIA BUANA Parung Panjang, terdapat beberapa hambatan-hambatan tertentu dalam mencapai hasil belajar, dapat bersifat psikologis, sosiologis maupun fisiologis, sehingga pada akhirnya dapat menyebabkan prestasi belajar yang dicapai berada di bawah semestinya. Dalam belajar kita tidak bisa melepaskan diri dari beberapa hal yang dapat mengantarkan kita berhasil dalam belajar. Banyak orang yang belajar dengan susah payah, tetapi tidak mendapatkan hasil apa-apa, hanya kegagalan yang ditemui. Penyebabnya tidak lain karena belajar tidak teratur, tidak disiplin, tidak tahu bagaimana berkonsentrasi dalam belajar, mengabaikan masalah pengaturan waktu dalam belajar, istirahat yang tidak cukup, kurang bersemangat, dan kurang tidur. Menurut Abu Ahmadi dalam Syaiful Bahri Djamarah (2002:16) dikatakan sebab-sebab peserta didik tidak dapat berkonsentrasi dalam belajar antara lain: (1) Kurang minat terhadap mata pelajaran, (2) Banyak urusan-urusan yang sering mengganggu perhatian baik urusan luar maupun urusan pribadi, (3) Adanya gangguangangguan suara keras dan udara yang sangat panas dapat mengurangi konsentrasi, dan (4) Adanya gangguan kesehatan atau terlalu lelah.

Pendidikan

diharapkan berlangsung seumur hidup dan perlu dilakukan sedini mungkin pada generasi muda, sehingga sudah semestinya kalau pendidikan itu menjadi tugas, kewajiban, dan tanggung jawab dari pemerintah, orang tua dan masyarakat. Sebagai penyelenggara pendidikan, pemerintah bersama-sama dengan orang tua dan masyarakat yakni membimbing, membina, dan membangun pendidikan bangsa untuk dapat meningkatkan kualitas sumber daya manusia.

Undang-undang RI Nomor 20 Tahun 2003 tentang sistem pendidikan nasional (2006:119) menjelaskan: Pendidikan nasional berfungsi mengembangkan kemampuan dan membentuk watak serta peradaban bangsa yang bermartabat dalam rangka mencerdaskan kehidupan bangsa, bertujuan untuk berkembangnya potensi peserta didik agar menjadi manusia yang beriman 
dan bertakwa kepada Tuhan Yang Maha Esa, berakhlak mulia, sehat, berilmu, cakap, kreatif, mandiri, dan menjadi warga negara yang demokratis serta bertanggung jawab. Para peserta didik SMA MULIA BUANA Parung Panjang ini merupakan bagian dari kelompok generasi muda bangsa Indonesia yang keberhasilan atau kegagalan mereka dalam menyelesaikan perkembangannya melalui proses pendidikan mempunyai hubungan yang erat dengan keberhasilan atau kegagalan kehidupan bangsa dimasa mendatang. Melalui pendidikan diharapkan dapat menghasilkan tenaga-tenaga yang cerdas dan terampil.

\section{A. Bimbingan Belajar}

Bimbingan belajar memiliki dua makna yaitu bimbingan secara umum yang mempunyai arti sama dengan mendidik atau menanamkan nilainilai, membina moral, mengarahkan peserta didik supaya menjadi orang baik. Sedangkan makna bimbingan yang secara khusus yaitu sebagai suatu upaya atau program membantu mengoptimalkan perkembangan peserta didik. Bimbingan ini diberikan melalui bantuan pemecahan masalah yang dihadapi, serta dorongan bagi pengembangan potensi-potensi yang dimiliki peserta didik.

Menurut Syamsu Yusuf dan Juntika Nurihsan (2005:82), Bimbingan dapat diartikan sebagai upaya pemberian bantuan kepada peserta didik dalam rangka mencapai perkembangannya yang lebih optimal.

Menurut Moh. Surya dalam

Dewa Ketut Sukardi (2000:20), Bimbingan adalah suatu proses pemberian bantuan yang terusmenerus dan sistematis dari pembimbing kepada yang dibimbing agar tercapai kemandirian dalam pemahaman diri dan perwujudan diri dalam mencapai tingkat perkembangan yang optimal dan menyesuaikan diri dengan lingkungannya.

Menurut Rochman Natawidjaja dalam Syamsu Yusuf (2005:6) berpendapat Bimbingan dapat diartikan sebagai suatu proses pemberian bantuan kepada individu tersebut dapat memahami dirinya sendiri, sehingga dia sanggup mengarahkan dirinya dan dapat bertindak secara wajar sesuai dengan tuntutan dan keadaan lingkungan sekolah, keluarga, masyarakat dan kehidupan pada umumnya. Dengan demikian, dia akan dapat menikmayi kebahagian hidupnya dan dapat memberikan sumbangan yang berarti kepada kehidupan masyarakat pada umumnya. Bimbingan dapat membantu individu mencapai perkembangan diri secara optimal sebagai mahluk sosial.

Menurut Prayitno dalam Dewa Ketut Sukardi (200:20), Bimbingan merupakan bantuan yang diberikan kepada seseorang (individu) atau sekelompok orang agar mereka itu dapat berkembang menjadi pribadipribadi yang mandiri. Kemandirian ini mencakup lima fungsi pokok yang hendaknya dijalankan oleh pribadi mandiri, yaitu: (a) mengenal diri sendiri dan lingkungannya, (b) menerima diri sendiri dan lingkungan secara positif dan dinamis, (c) mengambil keputusan, mengarahkan diri, dan (e) mewujudkan diri.

Berdasarkan beberapa definisi diatas, dapat diketahui bahwa bimbingan merupakan suatu proses yang berkesinambungan, sehingga bantuan itu diberikan secara sistematis, berencana, terus-menerus, dan terarah kepada tujuan tertentu. 
Dengan demikian kegiatan bimbingan bukanlah kegiatan yang asal-asalan. Bimbingan merupakan proses membantu individu, dengan menggunakan kata membantu berarti dalam kegiatan bimbingan tidak adanya unsur paksaan, bahwa bantuan diberikan kepada setiap individu yang memerlukannya didalam proses perkembangannya dan bantuan yang diberikan melalui pelayanan bimbingan bertujuan agar individu dapat mengembangkan dirinya secara optimal sesuai dengan potensi yang dimilikinya.

Dengan demikian bimbingan belajar dapat diartikan sebagai proses pemberian bantuan dari guru atau guru pembimbing kepada peserta didik agar terhindar dari kesulitan belajar yang mungkin muncul selama proses pembelajaran, sehingga peserta didik dapat mencapai hasil belajar yang optimal, dan optimal dalam kontek belajar dapat dimaknai sebagai pesrta didik yang efektif, produktif dan prestatif. Dapat diberi kesimpulan bahwa bimbingan belajar adalah suatu proses pemberian bantuan terusmenerus dan sistematis kepada individu atau peserta didik dalam memecahkan masalah yang dihadapinya terkait dengan kegiatan belajar. Adapun privat atau bimbingan individu menunjukkan usaha-usaha yang sistematis dan berencana membantu peserta didik secara perorangan agar dapat mengatasi masalah yang sedang dihadapinya. Sedangkan belajar kelompok merupakan suatu kegiatan yang dilakukan oleh dua atau lebih untuk membahas suatu materi dalam pelajaran yang sedang dihadapinya.

Menurut Mulyasa (2009:125), bentuk bimbingan yang diberikan kepada peserta didik dengan latar belakang masalahnya masing-masing sebagai berikut: (1) Pemberian informasi tentang cara-cara belajar yang efektif, baik belajar di sekolah maupun di rumah, (2) Bantuan penempatan, yakni menempatkan peserta didik dalam kelompokkelompok kegiatan yang sesuai, (3) Mengadakan pertemuan dengan orang tua untuk melakukan konsultasi, (4) Memberikan pembelajaran remedi, yakni mengadakan pembelajaran kembali atau pembelajaran ulang secara khusus, (5) Menyajikan pembelajaran secara konkrit dan aktual kepada peserta didik, (6) Memberikan layanan konseling bagi peserta didik yang menghadapi kesulitan-kesulitan emosional, (7) Memberikan perhatian khusus kepada peserta didik yang lamban.

Guru sebagai pembimbing dituntut untuk mengadakan pendekatan bukan saja melalui pendekatan instruksional akan tetapi dibarengi dengan pendekatan yang bersifat pribadi dalam setiap proses belajar mengajar berlangsung. Dengan pendekatan pribadi semacam ini guru akan secara langsung mengenal dan memahami peserta didiknya secara lebih mendalam sehingga dapat memperoleh hasil yang optimal.

\section{B. Prestasi Belajar}

Pengertian Prestasi menurut Kamus Besar Bahasa Indonesia adalah hasil yang telah dicapai dari apa yang telah dilakukan, dikerjakan, diusahakan dan sebagainya (Badudu dan Zain, 2001:1088). Hasil ini dapat dinyatakan dengan kuantitatif dan kualitatif, sedangkan yang dimaksud berprestasi adalah apabila anak didik mencapai hasil yang maksimal dari apa yang telah dilakukan sebelumnya. Apabila dihubungkan dengan kegiatan belajar anak didik, maka prestasi merupakan kecakapan khusus dan nyata yang dicapai secara maksimal 
sebagai hasil hasil dari belajar, dan sebagai ukuran untuk mengetahui seberapa jauh peserta didik telah menguasai bahan materi yang telah diberikan salah satunya yaitu melalui penilaian hasil belajar yang diwujudkan dalam bentuk raport, dengan raport maka akan dapat diketahui tentang prestasi belajar yang diraih oleh peserta didik.

Menurut Syaiful Bahri Djamarah (2002:88) memberi pengertian prestasi belajar sebagai berikut, "Prestasi belajar adalah hasil yang diperoleh berupa kesan-kesan yang mengakibatkan perubahan dalam diri individu sebagai hasil dari aktivitas dalam belajar". Prestasi belajar merupakan hasil yang dicapai atau ditunjukkan oleh peserta didik sebagai belajarnya baik berupa angka ataupun huruf serta tindakan yang mencerminkan hasil belajar yang dicapai atau ditunjukkan oleh peserta didik.

Menurut Muhibbin Syah (2004:196), tujuan dari hasil belajar (evaluasi) adalah: (1) Untuk mengetahui tingkat kemampuan yang telah dicapai oleh peserta didik dalam waktu kurun waktu tertentu, hal ini berarti dengan evaluasi guru belajar dan mengajar yang melibatkan dirinya selaku pembimbing dan pembantu kegiatan belajar pserta didiknya, (2) Untuk mengetahui posisi atau kedudukan seseorang peserta didik dalam kelompok kelasnya, dengan demikian hasil evaluasi itu dapat dijadikan guru sebagai alat penetap apakah peserta didik tersebut termasuk kategori cepat, sedang atau lambat dalam arti mutu kemampuan belajarnya, (3) Untuk mengetahui tingkat usaha yang dilakukan peserta didik dalam belajar, hal ini berarti bahwa dengan evaluasi, guru akan dapat mengetahui gambaran tingkat usaha peserta didik, hasil baik pada umumnya menunjukkan adanya tingkat usaha efisien, sedangkan hasil yang buruk adalah cerminan usaha yang tidak efisien, (4) Untuk mengetahui hingga sejauh mana peserta didik telah mendayagunakan kapasitas kognitifnya untuk keperluan belajar, jadi hasil akhir evaluasi itu dapat dijadikan guru sebagai gambaran realisasi pemanfaatan kecerdasan peserta didik, (5) Untuk mengetahui tingkat daya guna dan hasil guna metode mengajarnya yang telah digunakan guru dalam proses pembelajaran, dengan demikian apabila sebuah metode yang digunakan guru tidak mendorong munculnya prestasi yang memuaskan guru sebaiknya mengganti metode tersebut atau mengkombinasikannya dengan metode lain yang serasi. Dengan demikian tujuan prestasi belajar yang dicapai oleh peserta didik, merupakan hasil evaluasi belajar yang dapat terlihat pada perubahan tingkah laku anak, sejauh mana tingkat kecerdasan anak tersebut, dan perubahan lain menuju arah yang lebih baik. Perubahan perilaku anak didik tersebut boleh jadi berupa peningkatan kapabilitas dalam berbagai kinerja, sikap, minat atau nilai.

Menurut Nana Sudjana (2009:23) menjelaskan bahwa,"Hasil belajar dalam ranah kognitif berupa pengetahuan, pemahaman, aplikasi, analisis, sintesis, dan evaluasi”. Pengetahuan merupakan hasil belajar paling awal yang biasanya diterapkan dalam pembelajaran yang bersifat hafalan seperti rumus, definisi, istilah, perundangan, dan lainnya. Setelah pengetahuan tingkat berikutnya adalah pemahaman yang terdiri dari pemahaman terjemahan arti sebenarnya, pemahaman penafsiran dengan menghubungkan suatu pemahaman dengan pemahaman 
terhadap makna di balik pemahaman yang tampak. Tahapan kognitif aplikasi berupa penggunaan abstraksi pada situasi kongkret atau situasi khusus yang dapat berupa ide, teori atau petunjuk teknis. Tahap aplikasi dapat diterapkan untuk menjelaskan suatu gejala baru berdasarkan gejala yang telah diketahui sebelumnya. Tahap analisis merupakan tahap memilah suatu integritas menjadi bagian-bagian sehingga jelas susunannya, dengan analisis diharapkan peserta anak didik mempunyai pemahaman yang komprehensif dan terpadu sehingga mampu mengaplikasikannya pada situasi baru yang kreatif. Pada tahap evaluasi peserta didik telah mampu membuat suatu keputusan tentang nilai berdasarkan tujuan, gagasan, metode, dan lain-lain.

Belajar afektif berhubungan dengan sikap dan nilai, dalam masyarakat pada umumnya berkembang asumsi bahwa ranah afektif tidak dapat diukur, namun beberapa ahli menyatakan bahwa seseorang dapat diramalkan perubahannya, bila seseorang telah memiliki penguasaan kognitif tingkat tinggi. Nana Sudjana (2009:30), mengkategorikan lima jenis hasil belajar afektif, yaitu: (a) Penerimaan, yang berupa kepekaan dalam menerima stimulan dari luar yang berbentuk masalah, situasi, gejala dan lain-lain, (b) Tanggapan, berupa reaksi yang diberikan terhadap stimulan dari luar seperti perasaan, ketepatan reaksi, dan kepuasan dalam menjawab stimulan, (c) Penilaian, berhubungan dengan nilai dan kepercayaan terhadap gejala dan stimulus seperti penerimaan terhadap nilai atau kesepakatan terhadap nilai, (d) Organisasi, berupa pengembangan nilai ke dalam suatu sistem organisasi seperti konsep tentang nilai maupun organisasi nilai, (e) Karakteristik nilai, yaitu perpaduan sistem nilai yang mempengaruhi terhadap kepribadian dan perilakunya.

Hasil Belajar Psikomotorik tampak dalam ketrampilan dan akyivitas siswa. Menurut Nana Sudjana (2009:31), hasil belajar psikomotorik merupakan tahap kelanjutan dari belajar afektif, sehingga aktivitas yang muncul merupakan kelanjutan dari sikap (afektif).

\section{METODE PENELITIAN}

1. Studi Literatur

Studi literatur dilakukan dengan membaca buku literatur tentang bimbingan belajar dan prestasi belajar peserta didik, selain itu juga melakukan rujukan elektronik dari internet tentang bimbingan belajar dan prestasi belajar.

2. Observasi

Observasi dilakukan dalam bentuk observasi perilaku dengan cara penyebaran kuesioner secara Non probability Sampling jenuh, maksudnya semua responden dalam populasi dijadikan sampling. Populasi dalam penelitian, yaitu peserta didik kelas XI-IPS pada SMA MULIA BUANA Parung Panjang, yang berjumlah populasi 30 orang.

\section{III.PEMBAHASAN}

\section{A. Deskripsi Data Hasil Penelitian}

\section{Bimbingan Belajar}

Data variabel $\mathrm{X}$ yang diolah adalah sejumlah 20 pernyataan, dari data yang terkumpul dilakukan pembobotan pada jawaban responden untuk memudahkan analisis. 


\begin{tabular}{|c|c|}
\hline Responden & Skor Angket \\
\hline 1 & 85 \\
\hline 2 & 90 \\
\hline 3 & 87 \\
\hline 4 & 86 \\
\hline 5 & 86 \\
\hline 6 & 82 \\
\hline 7 & 85 \\
\hline 8 & 89 \\
\hline 9 & 78 \\
\hline 10 & 88 \\
\hline 11 & 89 \\
\hline 12 & 88 \\
\hline 13 & 87 \\
\hline 14 & 75 \\
\hline 15 & 80 \\
\hline 16 & 85 \\
\hline 17 & 78 \\
\hline 18 & 86 \\
\hline 19 & 85 \\
\hline 20 & 84 \\
\hline 21 & 74 \\
\hline 22 & 74 \\
\hline 23 & 78 \\
\hline 24 & 82 \\
\hline 25 & 85 \\
\hline 26 & 79 \\
\hline 27 & 87 \\
\hline 28 & 75 \\
\hline 29 & 67 \\
\hline 30 & 76 \\
\hline
\end{tabular}

Tabel 1: Data untuk penilaian Bimbingan

\section{Belajar}

Berddasarkan Tabel 1, maka dihitung rata-rata (mean) dari variabel bimbingan belajar, yaitu:

a. Mencari rentang (R)

$$
\begin{aligned}
\mathrm{R} & =90-67 \\
& =23
\end{aligned}
$$

b. Mencari jumlah kelas (K), dengan aturan Sturges

$$
\begin{aligned}
\mathrm{K} & =1+3,3 \log \mathrm{n} \\
& =1+3,3 \log 30 \\
& =1+3,3(1,477) \\
& =1+4,874 \\
& =5,874 \\
& =6 \text { (hasil pembulatan) }
\end{aligned}
$$

c. Mencari kelas interval (I)

$$
\begin{aligned}
\mathrm{I} & =\frac{\mathrm{R}}{\mathrm{K}} \\
& =\frac{23}{6} \\
& =3,83 \\
& =4 \text { (hasil pembulatan) }
\end{aligned}
$$

d. Tabel distribusi frekuensi variabel X

\begin{tabular}{|cccc|}
\hline SKOR & F & Xi & F.Xi \\
\hline $\mathbf{6 7}-\mathbf{7 0 , 8}$ & 1 & 68,9 & 68,9 \\
\hline $\mathbf{7 1 - \mathbf { 7 4 , 8 }}$ & 2 & 72,9 & 145,8 \\
\hline $\mathbf{7 5}-\mathbf{7 8 , 8}$ & 6 & 76,9 & 461,4 \\
\hline $\mathbf{7 9 - 8 2 , 8}$ & 4 & 80,9 & 323,6 \\
\hline $\mathbf{8 3 - 8 6 , 8}$ & 9 & 84,9 & 764,1 \\
\hline $\mathbf{8 7}-\mathbf{9 0 , 8}$ & 8 & 88,9 & 711,2 \\
\hline JUMLAH & $\mathbf{3 0}$ & & $\mathbf{2 4 7 5}$ \\
\hline
\end{tabular}

Tabel 2: $\quad$ Distribusi $\quad$ Frekuensi Variabel X

Berdasarkan data Tabel 2, nilai rata-rata (mean) variabel $\mathrm{X}$, adalah:

$$
\begin{aligned}
\text { Mean } & =\frac{\sum f \mathrm{x}}{\sum \mathrm{f}} \\
& =2475
\end{aligned}
$$


Dari Tabel 3. keadaan bimbingan

$=82,5$

Nilai rata-rata variabel $\mathrm{X}$ diperoleh angka 82,5 termasuk kategori baik sekali dengan skala tertinggi 100, artinya penilaian bimbingan belajar sudah sesuai standar

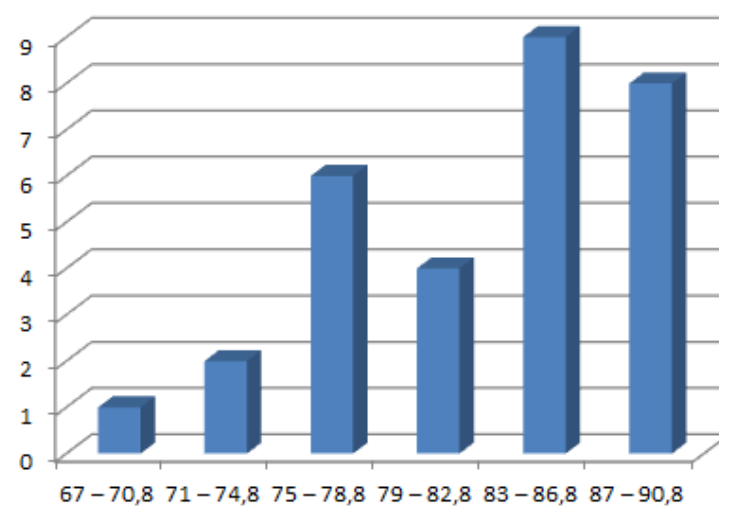

Gambar 1: Grafik Batang Distribusi

Frekuensi Variabel X

Berdasarkan Tabel 2. Distribusi Frekuensi Variabel $\mathrm{X}$, dapat digambarkan bagaimana keadaan bimbingan belajar pada SMA MULIA BUANA Parung Panjang, sebagai berikut:

\begin{tabular}{|c|c|c|c|c|}
\hline $\begin{array}{l}\mathbf{N} \\
\mathbf{0}\end{array}$ & $\begin{array}{l}\text { Variabe } \\
\text { l }\end{array}$ & $\begin{array}{l}\text { Kateg } \\
\text { ori }\end{array}$ & $\begin{array}{l}\text { Juml } \\
\text { ah }\end{array}$ & $\%$ \\
\hline \multirow[t]{3}{*}{1} & \multirow{3}{*}{$\begin{array}{l}\text { Bimbing } \\
\text { an } \\
\text { Belajar }\end{array}$} & $\begin{array}{l}\text { Renda } \\
\text { h }\end{array}$ & 3 & 10 \\
\hline & & Sedang & 10 & $\begin{array}{l}33.3 \\
3\end{array}$ \\
\hline & & Tinggi & 17 & $\begin{array}{l}56,6 \\
7\end{array}$ \\
\hline & Tota & & 30 & 100 \\
\hline
\end{tabular}

Tabel 3: Keadaan Bimbingan Belajar belajar di SMA MULIA BUANA Parung Panjang, memberi gambaran bahwa data variabel bimbingan belajar dari 30 responden dapat diklasifikasikan dengan pemberian jawaban terdapat 3 murid atau $10 \%$ murid berkategori rendah, 10 murid atau 33,33\% murid berkategori sedang, dan 17 murid atau 56,67\% murid berkategori tinggi. Dengan demikian dapat disimpulkan bahwa nilai bimbingan belajar di SMA MULIA BUANA Parung Panjang dalam kategori tinggi.

\section{Prestasi Belajar}

Berikut ini adalah data variabel $\mathrm{Y}$ pada SMA MULIA BUANA Parung Panjang.

\begin{tabular}{|clcc|}
\hline No & \multicolumn{1}{c}{$\begin{array}{c}\text { Nama } \\
\text { Responden }\end{array}$} & $\begin{array}{c}\text { Hasil Belajar } \\
\text { Siswa }\end{array}$ \\
\cline { 3 - 4 } & & Nilai & KKM \\
& & & \\
\hline 1 & Wahyu & 86 & L \\
\hline 2 & Budi Haryanto & 80 & L \\
\hline 3 & Wati Herawati & 90 & L \\
\hline 4 & Ani & 84 & L \\
& Purwaningsih & & \\
\hline 5 & Dina Mardiana & 86 & L \\
\hline 6 & Mawar Amelia & 64 & L \\
\hline 7 & Herlina & 80 & L \\
\hline 8 & Bagas Aditya & 84 & L \\
\hline 9 & Maya Wulandari & 78 & L \\
\hline 10 & Hendra & 80 & L \\
\hline 11 & Rizal & 72 & TL \\
\hline 12 & Indra Gunawan & 85 & L \\
\hline 13 & Irma Ningsih & 80 & L \\
\hline 14 & Sri & 80 & L \\
& Purwaningsih & & \\
\hline 15 & Agung Budianto & 84 & L \\
\hline & & & 58 \\
\hline & & & \\
\hline
\end{tabular}




\begin{tabular}{|clcc|}
\hline 16 & Wira Purwanto & 85 & L \\
\hline 17 & Bahktiar Baksin & 78 & L \\
\hline 18 & Yunita Pratiwi & 82 & L \\
\hline 19 & Angga Budiman & 85 & L \\
\hline 20 & Marlinawati & 78 & L \\
\hline 21 & Lisa Maria & 70 & L \\
\hline 22 & Martius & 85 & L \\
\hline 23 & Rosalina & 88 & L \\
\hline 24 & Teguh Santoso & 85 & L \\
\hline 25 & Warjiyono & 95 & L \\
\hline 26 & Achmad Arifin & 66 & L \\
\hline 27 & Syamsul & 75 & L \\
\hline 28 & Sopian Aryo & 85 & L \\
\hline 29 & Andi Solihin & 55 & TL \\
\hline 30 & Margaretha & 80 & L \\
\hline
\end{tabular}

Tabel 4. Data Penilaian Prestasi Belajar Mata

Pelajaran Ekonomi Kelas XIIPS

Panjang

SMA MULIA BUANA Parung

Keterangan :

KKM $=$ Kreteria Kelulusan Murid (60)

$\mathrm{L} \quad=$ Lulus $($ Nilai $\geq$ KKM $)$

TL = Tidak Lulus ( Nilai $<$

Berdasarkan Tabel 4. Data Penilaian Prestasi Mata Pelajaran Ekonomi Kelas XI-IPS SMA MULIA BUANA Parung Panjang, maka ratarata (mean) dari variabel Y Prestasi Belajar peserta didik, sebagai berikut:

a. Mencari rentang (R)

$$
\begin{aligned}
\mathrm{R} & =95-55 \\
& =40
\end{aligned}
$$

b. Mencari jumlah kelas (K), aturan Sturges

$$
\begin{aligned}
\mathrm{K} & =1+3,3 \log \mathrm{n} \\
& =1+3,3 \log 30 \\
& =1+3,3(1,4771)
\end{aligned}
$$

$$
\begin{aligned}
& =1+4,8744 \\
& =5,8744 \\
& =6 \text { (hasil pembulatan) }
\end{aligned}
$$

c. Mencari kelas interval (I)

$$
\begin{aligned}
& =\frac{\mathrm{K}}{\mathrm{K}}^{\mathrm{40}} \\
& =\frac{6,6}{6} \\
& =7 \text { (hasil pembulatan) }
\end{aligned}
$$

c. Tabel Distribusi Frekuensi Variabel Y

\begin{tabular}{|cccc|}
\hline SKOR & F & Xi & F.Xi \\
\hline $\mathbf{5 4 - 6 0 , 6}$ & 1 & 57,3 & 57,3 \\
\hline $\mathbf{6 1}-\mathbf{6 7 , 6}$ & 2 & 64,3 & 128,6 \\
\hline $\mathbf{6 8}-\mathbf{7 4 , 6}$ & 2 & 71,3 & 142,6 \\
\hline $\mathbf{7 5 - 8 1 , 6}$ & 10 & 78,3 & 783 \\
\hline $\mathbf{8 2}-\mathbf{8 8 , 6}$ & 13 & 85,3 & 1108,9 \\
\hline $\mathbf{8 9 - 9 5 . 6}$ & 2 & 92,3 & 184,8 \\
\hline JUMLAH & $\mathbf{3 0}$ & & $\mathbf{2 4 0 5 , 2}$ \\
\hline
\end{tabular}

Tabel 5. Distribusi Frekuensi Variabel Y

Berdasarkan data Tabel 2, nilai rata-rata (mean) variabel $\mathrm{X}$, adalah:

$$
\begin{aligned}
\text { Mean } & =\frac{\sum \mathrm{fx}}{\sum \mathrm{f}} \\
& =\frac{2405,2}{30} \\
& =80,17
\end{aligned}
$$

Nilai rata-rata variabel Y diperoleh angka 80,17, maka termasuk kategori baik dengan skala tertinggi 100, 
artinya prestasi belajar mata pelajaran ekonomi di kelas XI-IPS SMA MULIA BUANA Parung Panjang sudah tercapai.

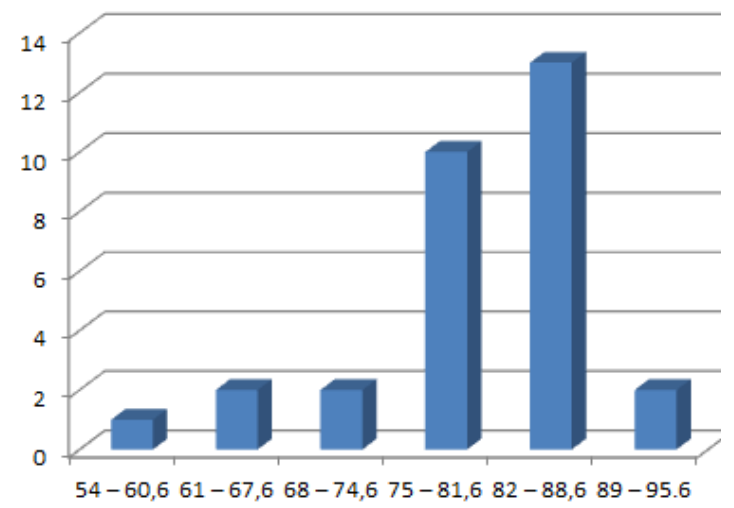

Gambar 2: Grafik

Batang

Frekuensi Variabel Y

Berdasarkan Tabel 5. Distribusi Frekuensi Variabel Y, dapat digambarkan bagaimana keadaan Prestasi Belajar mata pelajaran Ekonomi Kelas XI-IPS pada SMA MULIA BUANA Parung Panjang, sebagai berikut:

\begin{tabular}{|lllll|}
\hline $\mathbf{N}$ & Variab & & Katego \\
$\mathbf{0}$ & el & Jumla & ri \\
$\mathbf{1}$ & $\begin{array}{l}\text { Prestasi } \\
\text { Belajar }\end{array}$ & Rendah & 3 & 10 \\
\cline { 3 - 5 } & & Sedang & 12 & 40 \\
\cline { 3 - 5 } & & Tinggi & 15 & 50 \\
\hline & \multirow{2}{*}{ Total } & $\mathbf{3 0}$ & $\mathbf{1 0}$ \\
& & & $\mathbf{0}$ \\
\hline
\end{tabular}

Tabel 6: Keadaan Prestasi

Belajar Mata Pelajaran

Ekonomi Kelas XI-IPS SMA

Mulia Buana

Parung Panjang

Dari Tabel 6, memberi gambaran bahwa data variabel Y Prestasi Belajar

dari 30 responden dapat diklasifikasikan dengan pemberian jawaban terdapat 3 murid atau 10\% berkategori rendah, 10 murid atau 33,33\% berkategori sedang, dan 17 murid atau 56,67\% berkategori tinggi. Dengan demikian dapat disimpulkan bahwa nilai prestasi belajar untuk mata pelajaran ekonomi di SMA MULIA BUANA Parung Panjang dalam ketegori tinggi. Sebagai tolak ukur yang dijadikan standar penilaian adalah pendapat Suharsimi Arikunto (1999:245), yaitu:

\begin{tabular}{|ccc|}
\hline Angka & Huruf & Keterangan \\
\hline $81-100$ & A & Baik Sekali \\
\hline $66-80$ & B & Baik \\
\hline $56-65$ & C & Cukup \\
\hline $41-55$ & D & Kurang \\
\hline $0-40$ & E & Gagal \\
\hline
\end{tabular}

Tabel 7: Standar Koefisiensi Korelasi

\section{B. Analisis Data Hasil Penelitian}

\begin{tabular}{|cccccc|}
$\begin{array}{c}\text { Respo } \\
\text { den }\end{array}$ & $\mathbf{X}$ & $\mathbf{Y}$ & $\mathbf{X}^{2}$ & $\mathbf{Y}^{2}$ & $\mathbf{X . Y}$ \\
\hline $\mathbf{1}$ & 85 & 86 & $\begin{array}{c}722 \\
5\end{array}$ & $\begin{array}{c}739 \\
6\end{array}$ & $\begin{array}{c}731 \\
0\end{array}$ \\
\hline $\mathbf{2}$ & 90 & 80 & $\begin{array}{c}810 \\
0\end{array}$ & $\begin{array}{c}640 \\
0\end{array}$ & $\begin{array}{c}720 \\
0\end{array}$ \\
\hline $\mathbf{3}$ & 87 & 90 & $\begin{array}{c}756 \\
9\end{array}$ & $\begin{array}{c}810 \\
0\end{array}$ & $\begin{array}{c}783 \\
0\end{array}$ \\
\hline $\mathbf{4}$ & 86 & 84 & $\begin{array}{c}739 \\
6\end{array}$ & $\begin{array}{c}705 \\
6\end{array}$ & $\begin{array}{c}722 \\
4\end{array}$ \\
\hline $\mathbf{5}$ & 86 & 86 & $\begin{array}{c}739 \\
6\end{array}$ & $\begin{array}{c}739 \\
6\end{array}$ & $\begin{array}{c}739 \\
6\end{array}$ \\
\hline $\mathbf{6}$ & 82 & 64 & $\begin{array}{c}672 \\
4\end{array}$ & $\begin{array}{c}409 \\
6\end{array}$ & $\begin{array}{c}524 \\
8\end{array}$ \\
\hline $\mathbf{7}$ & 85 & 80 & $\begin{array}{c}722 \\
5\end{array}$ & $\begin{array}{c}640 \\
0\end{array}$ & $\begin{array}{c}680 \\
0\end{array}$ \\
\hline $\mathbf{8}$ & 89 & 84 & $\begin{array}{c}792 \\
1\end{array}$ & $\begin{array}{c}705 \\
6\end{array}$ & $\begin{array}{c}747 \\
6\end{array}$ \\
\hline $\mathbf{9}$ & 78 & 78 & $\begin{array}{c}608 \\
4\end{array}$ & $\begin{array}{c}608 \\
4\end{array}$ & $\begin{array}{c}608 \\
4\end{array}$ \\
\hline
\end{tabular}




\begin{tabular}{|c|c|c|c|c|c|}
\hline 10 & 88 & 80 & $\begin{array}{c}774 \\
4\end{array}$ & $\begin{array}{c}640 \\
0\end{array}$ & $\begin{array}{c}704 \\
0\end{array}$ \\
\hline \multirow{2}{*}{11} & \multirow{2}{*}{89} & \multirow{2}{*}{72} & 792 & 518 & 640 \\
\hline & & & 1 & 4 & 8 \\
\hline \multirow{2}{*}{12} & \multirow{2}{*}{88} & \multirow{2}{*}{85} & 774 & 722 & 748 \\
\hline & & & 4 & 5 & 0 \\
\hline \multirow{2}{*}{13} & \multirow{2}{*}{87} & \multirow{2}{*}{80} & 756 & 640 & 696 \\
\hline & & & 9 & 0 & 0 \\
\hline \multirow{2}{*}{14} & \multirow{2}{*}{75} & \multirow{2}{*}{80} & 562 & 640 & 600 \\
\hline & & & 5 & 0 & 0 \\
\hline \multirow{2}{*}{15} & \multirow{2}{*}{80} & \multirow{2}{*}{84} & 640 & 705 & 672 \\
\hline & & & 0 & 6 & 0 \\
\hline \multirow{2}{*}{16} & \multirow{2}{*}{85} & \multirow{2}{*}{85} & 722 & 722 & 722 \\
\hline & & & 5 & 5 & 5 \\
\hline \multirow{2}{*}{17} & \multirow{2}{*}{78} & \multirow{2}{*}{78} & 608 & 608 & 608 \\
\hline & & & 4 & 4 & 4 \\
\hline \multirow{2}{*}{18} & 86 & 87 & 739 & 672 & 705 \\
\hline & 86 & 82 & 6 & 4 & 2 \\
\hline 10 & 85 & 85 & 722 & 722 & 722 \\
\hline & & & 5 & 5 & 5 \\
\hline 20 & 84 & 78 & 705 & 608 & 655 \\
\hline & & & 6 & 4 & 2 \\
\hline 21 & 74 & 70 & 547 & 490 & 518 \\
\hline 21 & 14 & 10 & 6 & 0 & 0 \\
\hline & & & 547 & 722 & 629 \\
\hline 22 & 74 & 85 & 6 & 5 & 0 \\
\hline 23 & 78 & 88 & 608 & 774 & 686 \\
\hline 28 & 10 & & 4 & 4 & 4 \\
\hline 24 & 82 & 85 & 672 & 722 & 697 \\
\hline & & & 4 & 5 & 0 \\
\hline 25 & 85 & 95 & 722 & 902 & 807 \\
\hline & & & 5 & 5 & 5 \\
\hline & & & 624 & 435 & 521 \\
\hline 26 & 79 & 66 & 1 & 6 & 4 \\
\hline 27 & 87 & 75 & 756 & 562 & 652 \\
\hline 21 & $8 /$ & 15 & 9 & 5 & 5 \\
\hline 28 & 75 & 85 & 562 & 722 & 637 \\
\hline & & & 5 & 5 & 5 \\
\hline 29 & 67 & 55 & 448 & 302 & 368 \\
\hline & 07 & 53 & 9 & 5 & 5 \\
\hline 30 & 76 & 80 & 577 & 640 & 608 \\
\hline & & 00 & 6 & 0 & 0 \\
\hline Jumla & 24 & 24 & 204 & 194 & 198 \\
\hline h & 70 & 05 & 314 & 741 & 572 \\
\hline
\end{tabular}

Tabel 8: $\quad$ Angka

Yang

Diperlukan dalam

Perhitungan Regresi

Berdasarkan data yang tertera pada tabel 8 diatas, untuk membuktikan ada tidaknya pengaruh antara variabel $\mathrm{X}$ dengan variabel $\mathrm{Y}$, maka dapat dihitung dengan rumus regresi linier sebagai berikut:

1. Uji Regresi Sederhana (Regretion Test)

$$
{ }^{\wedge} Y=a+b X
$$

Perhitungan:

$$
\mathrm{b}=\frac{\mathrm{n} \cdot \sum \mathrm{XY}-\sum \mathrm{X} \cdot \sum \mathrm{Y}}{\mathrm{n} \cdot \sum \mathrm{X}^{2}-\left(\sum \mathrm{X}\right)^{2}}
$$

$$
\begin{aligned}
& =\frac{30(204.314)-(2.470)^{2}}{6.129 .420-6.100 .900} \\
& =\frac{16.810}{28.520} \\
b & =\frac{0,59}{\sum Y-b \cdot \sum X} \\
a & =\frac{n}{30} \\
& =\frac{2.405-0,59(2.470)}{30} \\
& =\frac{2.405-1.457,3}{947,7}
\end{aligned}
$$




$$
\begin{aligned}
& 30 \\
& =\quad 31,59
\end{aligned}
$$

Maka,

$$
\begin{aligned}
{ }^{\wedge} Y & =a+b X \\
& =31,59+0,59 X
\end{aligned}
$$

Membuat Garis Persamaan Regresi:

a. Menghitung rata-rata $\mathrm{X}$

$$
\text { 82,33 } \mathrm{X}=\frac{\sum \mathrm{X}}{\mathrm{n}}=\frac{2.470}{30}=
$$

b. Menghitung rata-rata $\mathrm{Y}$

$$
\mathrm{Y}=\underline{\sum \mathrm{Y}}=
$$

80,17

n $\quad 30$

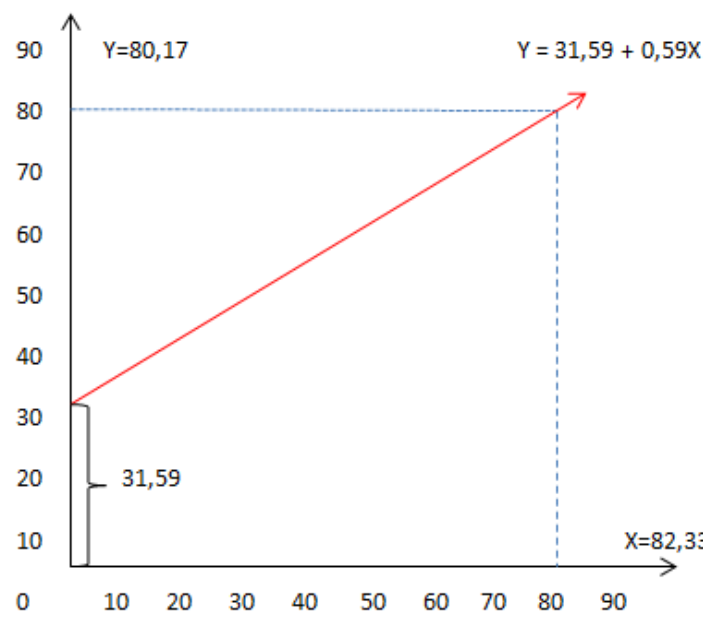

Gambar 3. Persamaan Garis Regresi

Persamaan regresi linier di atas membuktikan bahwa terdapat hubungan positif antara penilaian bimbingan belajar dengan prestasi belajar peserta didik pada SMA MULIA BUANA Parung Panjang, karena nilai koefisien bertanda positif yaitu 0,59 .

2. Uji Korelasi (Pearson Product Moment)

$r=\frac{n\left(\sum X Y\right)-\left(\sum X\right)\left(\sum Y\right)}{\sqrt{\left\{n \cdot \sum X^{2}-\left(\sum X\right)^{2}\right\} \cdot\left\{n \cdot \sum Y^{2}\right.}}-$ $\left.\left(\sum Y\right)^{2}\right\}$

$30(198.572)-(2.470)$

(2.405)

$\sqrt{\{30 \times 204314}$

$\left.(2470)^{2}\right\} .\left\{30 \times 194741-(2405)^{2}\right\}$

$5.957 .160-5.940 .350$

$\sqrt{\{6129420-6100900\} .\{5842230}$ $5784025\}$

16.810

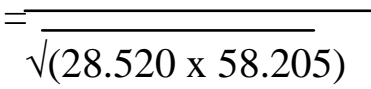

16.810

$=\overline{\sqrt{1.660 .006 .600}}$

16.810

$40.743,18$

$=0,412$

Berdasarkan hasil perhitungan korelasi di atas, terbukti bahwa pengaruh belajar (variabel X) dengan prestasi belajar (variabel Y) pada SMA MULIA BUANA Parung Panjang berkategori cukup yaitu 0,412. Dari perhitungan yang diperoleh diketahui bahwa $\mathrm{r}$ hitung sebesar 0,412 pada $n=30$. Jika dibandingkan antara $r$ hitung dengan $r$ 
tabel diperoleh 0,412 >0,361 ini artinya Ha diterima dan terdapat hubungan yang cukup erat antara bimbingan belajar dengan prestasi belajar ekonomi peserta didik di SMA MULIA BUANA Parung Panjang. Adapun penafsiran tinggi rendahnya suatu korelasi menurut Suharsimi Arikunto (1999:75), yaitu:

$$
\text { Antara } 0,800-1,00=\text { Sangat }
$$

Tinggi

$$
\begin{array}{ll}
\text { Antara } 0,600-0,800 & =\text { Tinggi } \\
\text { Antara 0,400-0,600 } & =\text { Cukup } \\
\text { Antara 0,200-0,400 } & =
\end{array}
$$

Rendah

Antara $0,00 \quad-0,200=$ Sangat Rendah

\section{Koefisien Penentu (KP)}

Untuk mengetahui berapa besar pengaruh bimbingan belajar dengan prestasi peserta didik pada SMA MULIA BUANA Parung Panjang dengan rumus Koefisien Penentu (Determinan) sebagai berikut:

$$
\begin{aligned}
\mathrm{KP} & =\mathrm{r}^{2} \times 100 \% \\
& =(0,412)^{2} \times 100 \% \\
& =0,1697 \times 100 \% \\
& =16,97 \%
\end{aligned}
$$

Berdasarkan hasil perhitungan Koefisien Determinasi di atas, dapat disimpulkan bahwa prestasi belajar peserta didik SMA MULIA BUANA 16,97\% dipengaruhi oleh variabel bimbingan belajar dari guru dan sisanya 83,03\% dipengaruhi oleh faktor lain.

\section{Pengujian Hipotesis}

Untuk pengujian signifikan menggunakan rumus uji $-\mathrm{t}$, sebagai berikut:

$$
r \sqrt{n-2}
$$

$$
\begin{aligned}
\mathrm{t} & =\frac{\sqrt{1-\mathrm{r}^{2}}}{0,412 \sqrt{30-2}} \\
& =\frac{0,412 \sqrt{28}}{\sqrt{1-(0,412)^{2}}} \\
& =\frac{0,412 \times 5,292}{\sqrt{1-0,1697}} \\
& =\frac{2,8303}{0,911} \\
& =\frac{2,180}{}
\end{aligned}
$$

Dari perhitungan di atas diperoleh harga $t$ hitung sebesar 2,393, selanjutnya jika dibandingkan dengan harga $\mathrm{t}$ tabel berdasarkan taraf signifikan $5 \%(\alpha=0,05)$ dengan derajat bebas $(\mathrm{db})=\mathrm{n}-2=30-2=$ 28, signifikan t tabel yaitu 1,701. Harga $\mathrm{t}$ hitung 2,393 $\geq \mathrm{t}$ tabel 1,701 dengan demikian Ha (Hipotesis yang diajukan) diterima. Hal ini berarti terdapat hubungan yang positif dan signifikan antara bimbingan belajar dengan prestasi belajar peserta didik pada SMA MULIA BUANA Parung Panjang. Uji hipotesis dapat digambarkan dalam kurva, sebagai berikut:

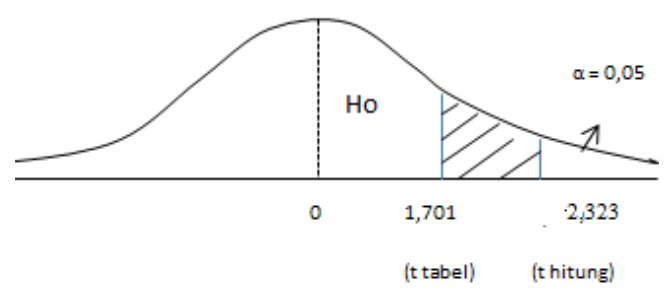

Gambar 4: Kurva Penolakan dan Penerimaan 


\section{IV.PENUTUP}

Penelitian ini membuktikan bahwasecara parsial ada pengaruh antara bimbingan belajar dan prestasi belajar peserta didik kelas XI-IPS SMA MULIA BUANA Parung Panjang. Dari perhitungan diperoleh hasil $\mathrm{r}$ hitung sebesar 0,412 pada $\mathrm{n}=$ 30, setelah dikonsultasikan dengan tabel harga kritik $\mathrm{r}$ tabel pada taraf signifikan 5\% diperoleh $r$ tabel sebesar 0,361 . Berdasarkan pengolahan data diatas maka $r$ hitung $0,412 \geq \mathrm{r}$ tabel 0,361 sehingga Ha diterima. Kesimpulannya terdapat hubungan yang signifikan antara bimbingan belajar dengan prestasi belajar peserta didik. Jika angka pada tabel dikonsultasilkan dengan harga interprestasi nilai $r$, dimana besar nilai $r$ tabel antara 0,200 - 0,400 hubungan tersebut tergolong rendah.

Dari perhitungan diperoleh $t$ hitung sebesar 2,393 selanjutnya jika dibandingkan dengan harga $\mathrm{t}$ tabel pada taraf signifikan $5 \%$ dan $\mathrm{db}=\mathrm{n}-2$ jadi $\mathrm{db}=30-2=28$, maka diperoleh $\mathrm{t}$ tabel pada taraf signifikan 5\% sebesar 1,701 , ternyata t hitung $2,393 \geq \mathrm{t}$ tabel 1,701. Dengan demikian Ha diterima, artinya terdapat hubungan yang signifikan antara bimbingan belajar dengan prestasi belajar peserta didik pada SMA MULIA BUANA Parung Panjang.

\section{DAFTAR PUSTAKA}

Ahmadi, Abu dan Widodo Supriyono, (2004), Psikologi Belajar (edisi revisi), Jakarta, Rineka Cipta.

Arikonto, Suharsimi, (2006), Prosedur Penelitian Suatu Pendekatan
Praktik (edisi revisi VI), Jakarta, Rineka Cipta.

dasar Evaluasi Pendidikan (edisi revisi), Jakarta, Bumi Aksara.

Badudu dan Zain Sutan Muhammad, (2001), Kamus Umum Bahasa Indonesia, Jakarta, Pustaka Sinar Harapan.

Erica, Denny, (2016), Pengaruh Bimbingan Belajar Terhadap Prestasi Belajar Peserta Didik (Studi Kasus SMA Kafah Unggul Tangerang), Cakrawala.

Dimyanti dan Mudjiono, (2006), Belajar dan Pembelajaran, Jakarta, Rineka Cipta,

Djamarah. Syaiful Bahri, (2002), Rahasis Sukses Belajar, Jakarta, Rineka Cipta.

Harjanto, (2008), Perencanaa Pengajaran, Jakarta, Rineka Cipta.

Ketut Sukardi, Dewa, (2000), Pengantar Pelaksanaan Program Bimbingan dan Konseling di Sekolah, Jakarta, Rineka Cipta.

Muhibbin Syah, (2004), Psikologi Belajar, Jakarta, Raja Grafindo Persada.

Sudjana, Nana, (2009), Penilaian Hasil Proses Belajar Mengajar, Bandung, Remaja Rosdakarya.

Sugiyono, (2007), Statistika Untuk Penelitian, Bandung, CV. Alfabeta. 
Syamsu Yusuf dan Juntika Nurihsan, (2005), Landasan Bimbingan dan Konseling, Bandung, Remaja Rosdakarya.

Undang-Undang RI Nomor 14 Tahun 2005 dan Nomor 20 Tahun 2003, (2006), Guru dan Dosen Serta Sistem Pendidikan Nasional, Bandung, Citra Umbara. 